\title{
Investigating the Effectiveness of Digital-Based Concept Mapping on Teaching Educational Technology for Undergraduate Students
}

\author{
Abdelrahman Ahmed* \\ Sultan Qaboos University, Sultanate of Oman \& Sudan University of Science and Technology, \\ Sudan \\ \& Ahmed Abdelraheem \\ Sultan Qaboos University, Sultanate of Oman
}

\author{
Received: $13 / 6 / 2016 \quad$ Accepted: 30/8/2016
}

\begin{abstract}
The purpose of this study was to investigate the effects of using digital-based concept mapping as strategy on students' achievements and attitudes. Data was collected from 58 students enrolled in the course of "Introduction to Educational Technology" in Instructional and Teaching Technologies Department at Sultan Qaboos University. Two sections out of four sections were selected randomly as the sample of the study. One of the sections was randomly chosen as experimental group $(n=27)$ and the other was control group $(n=31)$. Both pre- and postachievement tests were used. The results of the study revealed that students who were taught with digital-based concept mapping strategy performed better than those who were taught with the conventional method. There was a significant difference between male and female students in the post test scores of the experimental group in favor of females. In addition, no interaction effect for the independent variables was found. The study also showed that students in the experimental group had positive attitude towards using digital-based concept mapping in learning educational technology.
\end{abstract}

Keywords: Concept mapping, conventional instruction, educational technology.

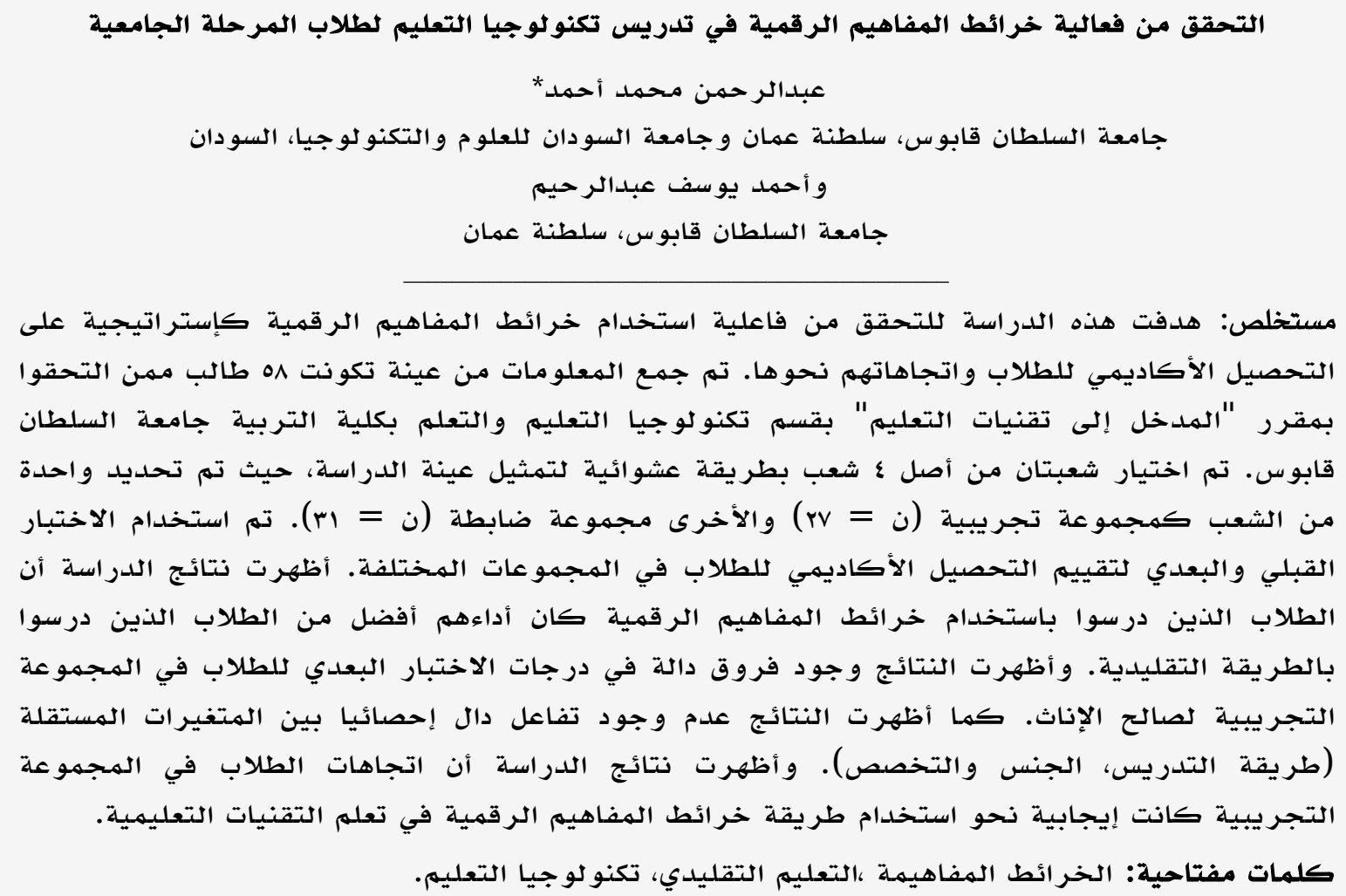

*abdo.art@gmail.com 
Traditional learning instruction focuses on learning strategies that are intended to teach specific course content. In Overcoming Resistance to Self-Direction in Adult Learning, Hiemstra (1994) points out that many traditional learning situations limit opportunities for personal involvement, especially where content is "controlled" by teachers. He states that by understanding how to locate resources and how to assess their learning progress, students can develop the skills and learner independence necessary for success in a variety of training or instructional settings. Understanding how students learn is an important issue in higher education, and currently the emphasis is on learner-centred strategies or strategies that teach learners how to learn. Sealfon (2012) recommended some of these strategies, including small group discussion, peer instruction, computer simulations and games, interactive lecture demonstrations, case studies, concept mapping, and tutorial worksheets. Concept mapping has been recognized as a cognitive tool that can empower learners to monitor and control their cognitive progress (Novak, 2010). With the rapid development of information and communication technology, concept mapping is no longer restricted to the construction of paper-based drawings (Hwang, $\mathrm{Wu}$, \& Kuo, 2013). Instead, students are able to modify their own concept maps conveniently via computerized concept mapping tools. The digital-based concept mapping tools can help students navigate the content and then interpret and organize their own knowledge based on their individual learning styles. Concept maps also develop student abilities in certain critical areas (Angelo \& Cross, 1993). Research by Hwang et al. (2013) indicated that the interactive whiteboard (IWB)-based concept mapping approach could improve students' learning attitudes towards the natural science course, whereas using concept maps with paper and pencil might have a detrimental effect on students' learning attitudes.

\section{Literature review}

As an instructional strategy, concept maps have become a widely used educational tool around the world to help students interpret and organize their personal knowledge. Concepts maps are based on Ausubel's meaningful learning theory. The underlying basis of the theory is that meaningful (as opposed to rote) human learning occurs when new knowledge is consciously and purposively linked to an existing framework of prior knowledge (Novak, 2006). According to this theory, students accommodate new concepts and ideas with existing knowledge in their cognitive structure (Novak, 2010). In a concept map, concepts (e.g., words, objects, pictures, formulas, symbols, etc.) are linked with lines and labelled as propositions (Reiska, Canas, Novak, \& Miller, 2008; Ruiz-Primo, Schultz,\& Shavelson, 1997; Chang, Sung, Chang,\& Lin, 2005; Novak \& Cañas, 2008). As such, the concept map is a collection of propositions that explains the connections between the concepts. In other words, a concept map is a "visual representation tool for organizing and representing knowledge in networks of concepts and linking statements about a problem or subject" (Novak \& Cañas, 2008, p.1). A concept map can be created and supported by tools such as graphic organizers and physical models, as well as by engaging students in kinaesthetic activities, that is, activities involving physical movement (Marzano, Pickering, \& Pollock, 2001). From those, perhaps the most commonly used visual learning tool is the graphic organizer, which includes diagrams depicting hierarchical information (e.g., concept maps, cause-effect relationships, such as the fishbone diagram), and free associations and links among ideas (e.g., mind maps). Graphic organizers help students not only "read" and comprehend complex information and relationships more easily but also generate ideas, structure their thoughts, and learn how to make what they know visible in an easy-to-read way. The latter requires that students understand the topic under study, discern relationships between concepts, and be able to prioritize information (Birbili, 2006). The traditional approach of concept mapping (paper and pencil) has several disadvantages. Firstly, concept maps produced in this way are difficult for students to modify and for teachers to evaluate, which often reduces their effectiveness (Hwang et al., 2013). Furthermore, with the traditional approach of concept mapping, the development process of the concept maps cannot be recorded and easily assessed. Therefore, digital concept mapping tools in web-based environments such as MindMup (www.mindmup.com) and MindMaple (www.mindmaple.com) can be used to create concept maps that allow learners to collaborate and share their works with their teachers and help teachers assess students' work. Con- 
sequently, the advancements in computerized applications and web-based tools could enable more alternatives for using concept maps in teaching and learning (Hwang et al., 2013).

The current study investigates the effectiveness of digital-based concept mapping in teaching educational technology concepts. Spider maps and network trees (Bellanca, 2007) were implemented in the study due to their features (see Figures 1 and 2 for the concept maps chosen in the research). Spider maps are for the organizing phase, and network trees are for the layout phase.

Source: Bellanca (2007, p. 87)

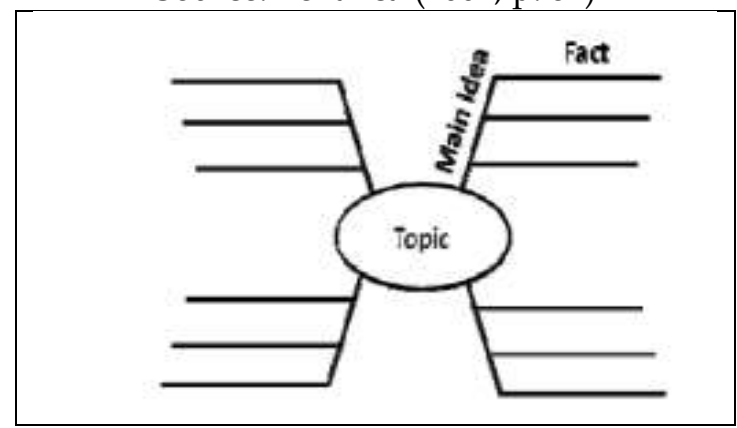

Figure 1: Spider map

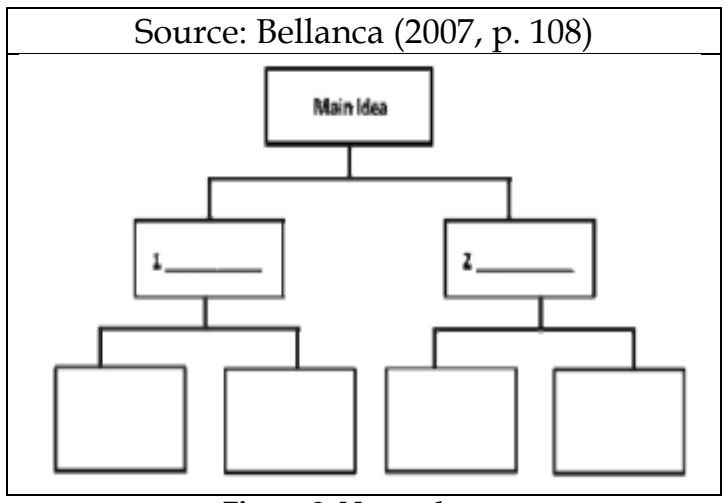

Figure 2: Network tree

The number of studies investigating the effects of digital-based concept mapping on educational technology is limited. Research conducted by Erdogan (2009) compared the effects of paper-based and computer-based concept mappings on computer hardware achievement, computer use anxiety, and computer attitude of the eight grade secondary school students. The students were allocated randomly to three groups and were given instructions on computer hardware. The teaching methods used for each group, respectively, were the conventional method, paper-based concept mapping, and computer-based concept mapping. The study found that the paperbased and computer-based concept mapping strategies produced better results than the conventional method. However, the effects of paper-based and computer-based concept mapping strategies were not significantly different. Similarly, Yen and Yang (2013) conducted a study aimed at scrutinizing the effects of digital concept mapping via Learning Management System (LMS) on English majors' $(\mathrm{N}=38)$ Microsoft PowerPoint (PPT) slide writing skills in Taiwan. Their results confirmed that analytical reading with digital concept mapping strategies could solve English as Foreign Language (EFL) students' PPT slide writing problems and improve their performance and the attainment of the task shares via LMS.

Several studies, however, have explored the effectiveness of concept mapping as an instructional strategy compared to the traditional teaching method. The focus of these studies has been on comparing the effectiveness of concept mapping (paper and pencil concept map) to traditional teaching practices such as the lecture method. Concept maps have been found beneficial for teaching students, for example, who are 25o studying financial accounting (Irvine, Cooper, \& Jones, 2006), library science (Colosimo \& Fitzgibbons, 2012), physics (Dennis, Chinyama, \& Jumbe, 2014), chemistry (BouJaoude \& Attieh, 2008; Emmanuel, 2013), mathematics (Williams, 1998), biology (Brinkerhoff \& Gary, 2013), and teaching (Cheema \& Mirza, 2013). The results from the majority of these studies indicated the obvious use of concept mapping in enhancing students' understanding of interrelated concepts and their use as a mechanism to improve learning.

In a study conducted by Luchembe, Chinyama, and Jumbe (2014) to show the effectiveness of concept mapping as a teaching strategy to undergraduate students taking an introductory physics course, the findings showed that concept mapping was more effective than the tutorial sheet strategy. The findings also showed that students had a positive attitude towards the use of concept mapping. Similarly, Sakiyo and Waziri (2015) have investigated the use of the concept mapping teaching method on secondary school students' academic achievement in biology. Their results revealed that the concept mapping method enhanced students' academic achievement in biology. They also found that there was no significant difference between male and fe- 
male students in the experimental group. Alhomaidan (2015) investigated the effect of using concept mapping on developing the learning outcome of college-level students studying at the College of Technology at Arrass. The post-test results showed that the experimental group members scored higher grades compared to their counterparts in the control group. Cheema and Mirza (2013) conducted a study to analyse the effect of concept mapping on academic performance of seventh-grade students in the subject of general science. Their results showed that the male and female students taught through concept mapping performed better than the students taught through traditional teaching methods. However, male students taught through concept mapping performed significantly better than the female students. In addition, Emmanuel (2013) investigated the effects of the concept mapping strategy on secondary school students' achievement on difficult chemistry concepts. The study also examined the differential effect on the achievement of male and female chemistry students. The results showed that students taught using the concept mapping strategy achieved higher and significantly better outcomes than those taught using the conventional method. Female students also performed better than their male counterparts using this method.

In a more recent study, Erdoğan (2016) investigated the experimental studies that test the effectiveness of the concept mapping instructional strategy compared to the traditional teaching method. In this study, 73 studies were selected that met the inclusion criteria. The results indicated that the effect of the concept mapping instructional strategy in terms of academic success was higher than the traditional method. Similarly, Akeju, Simpson, Rotimi, and Kenni (2011) conducted a study to investigate the effects of teaching with the concept mapping instructional strategy on learning achievement in Nigerian secondary schools. Their findings revealed that the concept mapping instructional strategy contributed to learning achievement in physics, and there was a significant effect in students' learning attitude. The results established that when integrated with any method of instruction, the instructional strategy resulted in improved learning achievement.

From the above literature and previous studies, it is clear that significant researches have explored the issue of concept maps in teaching and learning. The majority of these researches investigated the effect of concept mapping compared to traditional teaching practices on students' achievement in terms of their teaching method, gender, or specialty (Emmanuel, 2013; Luchembe et al., 2014; Sakiyo \& Waziri, 2015; Erdogan, 2009 and Erdoğan, 2016). Most of the previous studies researched in this study focused on comparing the effectiveness of concept mapping to traditional teaching in different areas (e.g., Soroush \& Fatemeh, 2013 and Sakiyo \& Waziri, 2015). However, there is only one study has been conducted on the effect of the digital concept mapping method on students' achievement in teaching (e.g., Erdoğan, 2009). But the current study is different from this study in terms of context, audience, subject matters and software used for mapping. Therefore, there is a need for more studies that empirically investigate the effect of the digital concept mapping method on students' achievement. For the maximum use and benefit of digital concept mapping there are certain condition should be met in the learning environment such as the availability of the different computer software programs, e.g. Inspiration and the free web-based tools.

\section{Importance of the study}

Besides the past research directions mentioned above, the College of Education at SQU is undergoing an accreditation process. Among the dimensions of the conceptual framework of the College of Education are diversified teaching and technological skills; therefore, the current study seeks integration of different teaching methods with technology skills. This study aims to help uncover the effectiveness of digital-based concept mapping by trying to answer the following research questions.

\section{Research questions:}

1. Does students' achievement in technology concepts vary according to instructional strategy (concept mapping vs. traditional methods)?

2. Does students' achievement vary according to their specialty (Science/Math, Physical Education, and Art Education)?

3. Does students' achievement vary according to their gender?

4. Is there any interaction effect between teaching strategy "group" and gender, 
teaching strategy and specialty, gender and specialty, teaching strategy, gender and specialty?

5. What are attitudes of the students towards digital concepts mapping?

\section{Purpose of the study}

The purpose of this study is to test the effectiveness of the proposed instructional strategy in teaching an introductory course in educational technology (TECH 3007), which is a three credit hour course taught for all students in the College of Education at SQU. In detail, the proposed study investigates the effects of digital-based concept mapping as an instructional strategy on achievement and determines whether students' attitudes vary according to the instructional method. It also examines the variations of achievement with gender, students' specialty and teaching methods.

\section{Method}

\section{Participants}

The target population was all undergraduate students who were studying or will be studying educational technology courses at the Department of Instructional and Learning Technologies in the College of Education at SQU in Oman $(\mathrm{N}=110)$. The sample consisted of the students who studied TECH 3007: Introduction to Educational Technology in the year $2015 / 2016$ at the second semester with a total number of $58(\mathrm{n}=58)$ participants divided into two groups. One group consisted of 27 students, and the other consisted of 31 students. The researchers chose one group randomly to be the experimental group, and the other became the control group.

\section{Instruments}

\section{Achievement tests (pre-test and post-test)}

Given the nature of this study, which required the identification of the student level of knowledge about the content covered before and after the experiment, an achievement test about technological concept knowledge and understanding was prepared on the basis of the unit objectives and featured items drawn from the set text. The achievement test items consisted of 25 questions (10 true/false questions and 15 multiple-choice questions, with one mark for each). However, in the light of the assessors' comments and suggestions, the achievement test was modified in its final draft to consist of 25 objective questions. To verify the face validity of the achievement test, it was submitted with the general aims, behavioural objectives, and content of the unit to a number of assessors from the department in order to benefit from their advice and comments regarding the suitability and clarity of test questions. The test was also piloted with 20 students who were not members of the study sample, and the level of difficulty was assessed, ranging from 0.18 to 0.51 , which was considered acceptable (Haladyna, Downing, \& Rodriguez, 2002). The reliability (internal consistency) was 0.87 and considered sufficient to use in the main study (Zinbarg, Yovel, Revelle, $\&$ McDonald, 2006). After preparation and confirmation of validity and reliability of the environment and research instruments, the teaching experiment was undertaken over an 8 -week block. The two groups were taught the same unit by the same instructor (who was one of the researchers) in each of the conditions.

\section{Attitude scale}

The present study used a questionnaire for assessing students' attitudes towards educational technology content through the concept mapping approach (Appendix 1). The researchers developed the concept map attitude scale. The survey consisted of 11 items containing positive and negative statements. The last 2 items were stated negatively, therefore, students response to this items was reversed $(1=5,2=4 \ldots)$. The Alpha Cronbach reliability for the total survey was 0.87 as measured by Alpha Cronbach. The response to scale ranges from 1 to 5 (absolutely agree, agree, am not sure, do not agree, and absolutely do not agree).

\section{Procedures}

To explore the relationships among teaching methods, students' attitudes, and academic performance, this study was conducted in a naturalistic setting using a quasi-experimental design with concept mapping as the treatment variable (Campbell \& Stanley, 1963; Cooper \& Schindler, 1998). The experimental group was required to create concept maps. Experimental research provides the best results for the cause and effect correlation of the experiment and comparison groups. The sample was randomized by design. The respondents came from 
two sections of the same course that had been randomly self-selected during the spring 2016 semester. As stated previously, the groups were distributed with 31 in the control group and 27 in the experimental group. The study was conducted at SQU. The class was an educational technology course, and the respondents were all students who registered for this course (TECH 3007: Introduction to Educational Technology). One instructor taught the two sections at two different times of the week. The students who agreed to participate in the study took a pre-test. At the beginning of the study, the researchers made an arrangement as to how the two sections of the class would be taught differently with the same materials. One of the classes used traditional teaching methods (e.g., lectures). The other class used the digital-based concept mapping method. The duration for this small experimental study was 8 weeks. The classes had a 4-hour class period every week. The chapter coverage was divided equally for both classes to provide equal distribution of the lessons that the experiment covered.

To construct a concept map for learning purposes, it is important to begin with a domain of knowledge that is very familiar to the learner constructing the map (Novak \& Cañas, 2008). It is also helpful for the learner to select a limited domain of knowledge for the first concept map. Before starting this experimental study, the instructor explained the aim and the advantages of the activity (using digital-based concept mapping) in order to motivate the students. After that, he introduced an explanation of what a concept map is, its objectives, and how it will be built and assessed. Thus, the instructor gave the learners clear instructions and steps for how to design and construct concept maps for learning. Two topics from the TECH3007 course were selected by the instructor to be taught using the digitalbased concept map strategy as a sample for the students. One of these topics was "ASSURE model" and the other was "classifying instructional media". After that, the instructor identified the key concepts that apply to these topics. For ASSURE model, 28 concepts were determined and listed. Then from this list, an ordered list was established from the most general and inclusive concept to the most specific to least general concept at the bottom of the list. The instructor then used different computer software programs such as Inspira- tion $^{\circledR}$ and iMindMap as well as the free webbased tools, for example, spiderscribe (www.spiderscribe.net), Bubbl. us (https://bubbl.us/), Mindmup (www.mindmup.com), and MindMaple (www.mindmaple.com), to construct the concept maps. Most of these web sites offer concept mapping tools for 30-day free trials. The majority of the students in the experiment study designed their digital-based concept maps by using the software Inspiration ${ }^{\circledR}$, which is clearly the most widely used. Finally, the maps were revised, concepts repositioned in ways that lend to clarity and better overall structure, and "final" maps were prepared and shared among all the learners.

Students in the experimental group were given the option of presenting the linkages between concepts for their maps using either spider maps or network trees. They were also asked to use any concept map tool (i.e., either software programs or free web-based tools) to organize their concepts. Then the students were encouraged to use as many words as they wanted to label the line between two concepts following the steps presented by the instructor. Appendix 2 shows samples of students' work on the digital-based concepts map designed by Inspiration ${ }^{\circledR}$. In addition, the students were asked to work either individually or in groups to create their digital concept maps. For the control group, the teaching method was a normal lecture type delivery. In this method, the instructor dominated the information presentation for the students by using a PowerPoint presentation and conventional teaching technique (lecturing). In addition to that, students were asked to work either individually or in groups for the lab sessions to do their assignments. At the end of the experimental treatment (8 weeks), a posttest was conducted for both classes to test for students' academic performance. An attitude scale was also conducted at the end of the experiment.

\section{Results}

\section{Pre-test}

The researchers conducted a pre-test before the experiment to ensure that the two groups were equivalent in terms of their achievement. An independent sample t-test was used for equivalency of scores in the achievement of the two groups. 
Table 1

Independent sample t-test scores for differences in means of the t-test score

\begin{tabular}{lccccccc}
\hline & Group & $\mathrm{N}$ & Mean & SD & p. & t & df \\
\hline Teaching & Control & 28 & 10.50 & 1.85 & .308 & 1.029 & 53 \\
method & $\begin{array}{c}\text { Exper- } \\
\text { imental }\end{array}$ & 27 & 9.92 & 2.26 & & & \\
& & & & & & \\
\hline
\end{tabular}

Table 1 shows that there is no significant differences in the means of the two groups (control and experimental group) in the pre-test $\left(t_{53}=1.029,0.308, p>0.05\right)$. Based on this analysis, the academic performances of the two groups (the experimental group and control group) were considered equivalent.

\section{Post-test}

To answer the research questions about the main effects (teaching methods, gender, and specialty) and interaction effects between the variables, a three-way analysis of variance was used. Table 2 and Table 3 show the statistics.

Table 2

Means and standard deviations of the three variables in

\begin{tabular}{llccc}
\multicolumn{5}{c}{ post-test scores } \\
\hline Variables & & $\mathrm{N}$ & Mean & SD \\
\hline \multirow{3}{*}{ Groups } & Control & 31 & 15.6129 & 1.54224 \\
& Experimental & 26 & 17.3077 & .78838 \\
Gender & Male & 10 & 15.50 & 2.01108 \\
& Female & 48 & 17.50 & 1.41170 \\
& Math/Science & 14 & 16.57 & .4654 \\
Specialty & Physical Education & 34 & 16.11 & .2524 \\
& Art Education & 7 & 17.20 & .3262 \\
\hline
\end{tabular}

Table 3 indicates that there is a significant difference in the mean scores of the post-test between the control group and the experimental group $($ F-value $=(10.062)$ with $\mathrm{df}=1,54$, significant at 0.003 ) in favour of the experimental group. This means that students taught educational technology concepts using digital-based concept mapping (mean=17.3077) performed better than those taught with the conventional method (mean=15.6129). This result could be justified by the fact that visual representation of concepts helps students visualize the different parts of the concepts together with their links. The students also can see the total picture of the concept. This finding agrees with many other findings (Akeju et al., 2011; Cheema \& Mirza, 2013; Emmanuel, 2013; Yen \& Yang, 2013; Luchembe, Chinyama, \& Jumbe, 2014; Sakiyo \& Waziri, 2015; Alhomaidan, 2015; Akınoğlu, Elmac, \& Gündoğdu, 2016; and Erdoğan, 2016), which all found that the concept mapping method enhanced students' academic achievement more than the traditional method. Yezka and Nasrabadi (2004) maintained that the concept mapping strategy has significant effects on meaningful learning and promotes students' academic achievement.

Table 3

Three-way between-subjects analysis of variance (ANCOVA)

\begin{tabular}{lrrrrr}
\hline \multicolumn{1}{c}{ Dependent Variable: Post-test } & & & & \\
\hline \multicolumn{1}{c}{ Source } & $\begin{array}{c}\text { Sum of } \\
\text { Squares }\end{array}$ & df & $\begin{array}{c}\text { Mean } \\
\text { Square }\end{array}$ & \multicolumn{1}{c}{ F } & Sig. \\
\hline Corrected Model & $61.941^{\mathrm{a}}$ & 9 & 6.882 & 4.722 & .000 \\
Intercept & 494.269 & 1 & 494.269 & 339.125 & .000 \\
Pre-test & .140 & 1 & .140 & .096 & .758 \\
Group & 14.666 & 1 & 14.666 & 10.062 & .003 \\
Specialty & 3.013 & 2 & 1.506 & 1.034 & .364 \\
Gender & 5.960 & 1 & 5.960 & 4.089 & .049 \\
Group * specialty & 4.520 & 1 & 4.520 & 3.101 & .085 \\
Group * gender & 3.300 & 1 & 3.300 & 2.264 & .139 \\
Specialty * gender & 1.305 & 2 & .652 & .448 & .642 \\
Group* specialty* & .000 & 0 & & & \\
gender & 65.587 & 45 & 1.457 & & \\
Error & 14986.000 & 55 & & & \\
Total & 127.527 & 54 & & & \\
Corrected Total & & & & & \\
\hline
\end{tabular}

a. R Squared $=.481$ (Adjusted R Squared $=.370$ )

Concerning the specialty variable with three levels, table 3 shows that there is no significant difference due to this variable, which means that the specialty is not affected by the intervention. This could be justified by the fact that concept maps are tools for organizing and representing knowledge to improve how students learn, to enhance how they interconnect what they learn (Maas \& Leauby, 2005), and to promote the meaningful and active learning across a wide range of disciplines. Thus, the results from the previous researches in this study confirmed that concept mapping techniques have aided students and promoted their academic achievement in many fields of knowledge, such as financial accounting (Irvine et al., 2006), physics (Denniset al., 2014), chemistry (BouJaoude \& Attieh, 2008; Emmanuel, 2013), mathematics (Williams, 1998), biology (Brinkerhoff \& Gary, 2013), and teaching (Cheema \& Mirza, 2013).

The gender variable was considered an important factor in research studies. Table 3 shows there is a significant difference in posttest scores of the male and female students in the experimental group in favour of female students $(F$-value $=(4.089)$ with $\mathrm{df}=(1,54)$ significant at .050). Table 2 showed that female $($ mean $=17.50)$ is greater than male (mean= 15.50), which indicated that female students taught through concept mapping performed significantly better than the male students. This finding is in concordance with those re- 
ported by Emmanuel (2013) and BouJaoude and Attieh (2008), who reported that the female students taught through concept mapping performed significantly better than the male students. However, this result contradicts the study by Cheema and Mirza (2013), which showed that the male students taught through concept mapping performed significantly better than the female students. Moreover, a more recent study by Sakiyo and Waziri (2015) found that there was no significant difference between male and female students in the experimental group who were taught through concept mapping. Regarding the interaction between independent variables, Table 3 shows there is no interaction effect between the group and spatiality, between the group and gender, between specialty and gender, and among group, specialty, and gender.

To answer the research question related to students' attitudes in experimental group, a questionnaire was used to assess their attitudes towards the use of digital concept mapping in learning educational technology. The descriptive statistics for their attitudes towards digital concept mapping learning strategy are shown in Table 4.

Table 4 shows that the students in experimental group had a positive attitude towards the use of digital concept mapping for learning educational technology concepts (mean = $4.19, \mathrm{SD}=0.4138)$. Table 4 shows that the top five statements regarding the positive attitudes from using digital concept mapping as viewed by the students were as follows: (a) I think the construction of the concept maps was very useful for my learning; (b) I enjoyed constructing concept maps; (c) I think the concept map strategy is very creative; (d) I think the concept maps promoted my ability to organize, think, and relate to prior knowledge; and, (e) I will use concept maps when revising other topics related to my specialty. These results indicated that digital-based concept mapping strategy can be used as an effective method for raising students' interest and promote their academic achievement for learning educational technology concepts.

This result could be justified by the fact that cognitive tools such as Inspiration ${ }^{\circledR}$ and MindMaple helped students interpret and organize their personal knowledge based on their individual learning styles (Reushle, Dorman, Evans, Kirkwood, McDonald, \& Worden, 2012). Moreover, digital-based concept mapping tools could help students benefit from learning visually (Bruillard \& Baron, 2000; Erdogan, 2009) and could inspire them to learn. The findings of Luchembe and his team (2014) partially support the results of this study; they reported that students had a positive attitude towards the use of concept mapping. The results are also supported by Soroush and Fatemeh (2013), who found that students' attitudes towards using concept maps as a tool that improves their listening comprehension ability was positive. We can conclude that digital concept mapping tools provide a dynamic and enjoyable atmosphere for the students that might have positively influenced their attitudes regarding learning educational technology concepts.

Table 4

Descriptive Statistics of the students' attitudes in experimental group towards digital concept mapping learning strategy

\begin{tabular}{|c|c|c|c|c|}
\hline & Item & $\mathrm{N}$ & Mean & SD \\
\hline 1. & I enjoyed constructing concept maps. & 23 & 4.4074 & .74726 \\
\hline 2. & I think the concept map strategy is very creative. & 23 & 4.3704 & .56488 \\
\hline 3. & I think the construction of the concept maps was very useful for my learning. & 23 & 4.5185 & .84900 \\
\hline 4. & The constructions of concept maps activities were motivating me. & 23 & 4.2593 & .71213 \\
\hline 5. & I feel that concept maps improved my thinking. & 23 & 4.1111 & .84732 \\
\hline 6. & $\begin{array}{l}\text { I think the concept maps promoted my ability to organize, think, and relate to } \\
\text { prior knowledge. }\end{array}$ & 23 & 4.2963 & .54171 \\
\hline 7. & I will use concept maps when revising other topics related to my specialty. & 23 & 4.2593 & .85901 \\
\hline 8. & $\begin{array}{l}\text { I will teach some topics using the concept maps strategy when I start my teach- } \\
\text { ing at school. }\end{array}$ & 23 & 4.2222 & .93370 \\
\hline 9. & $\begin{array}{l}\text { The construction of the concept map made me learn the concepts of education- } \\
\text { al technology better. }\end{array}$ & 23 & 4.0000 & .96077 \\
\hline 10. & $\begin{array}{l}\text { I prefer the traditional method of analysing topics more than using a concept } \\
\text { map. }\end{array}$ & 23 & 3.4074 & $\begin{array}{r}1.1522 \\
3\end{array}$ \\
\hline 11. & Instead of simplifying, the concept map just confused me more. & 23 & 4.2593 & .76423 \\
\hline & Overall & 27 & 4.1919 & 0.4138 \\
\hline
\end{tabular}




\section{Implications and Conclusion}

This paper investigated the effects of digitalbased concept mapping as an instructional strategy on achievement and attitude. The study found that there is a significant difference in the mean scores of the post-test between the control group and the experimental group in favour of the experimental group. The students taught using the digital-based concept mapping strategy performed better than those who were taught using the conventional method. The result also showed that there is no significant difference due to the specialty (Math/Science, Physical Education, and Art Education). There was also a significant difference in the post-test scores of the male and female students in the experimental group in favour of the female. In terms of interaction between independent variables, the result showed that there is no interaction effect between the group and spatiality, between the group and gender, between specialty and gender, and among group, specialty, and gender. The study also showed that students in the experimental group had positive attitudes towards using digital-based concept mapping in their learning of educational technology. Based on the results of this study, several implications can be addressed.

First because digital-based concept mapping is found to be an effective teaching strategy for improving students' achievement for educational technology concepts, instructors at SQU should use it as one of their teaching strategies to improve student performance. For effective use of digital-based concept mapping, a series of workshops could be conducted to help instructors in implementing this instructional strategy. The college of education should provide and maintain computer laboratories and purchases new and advance software that might encourage instructors and students to built digital-based concept mapping in their subjects.

Second, since digital concept mapping is an emerging teaching technique and the technology keep changing; instructors should encourage students to use digital-based concept mapping for different topics, chapters, courses and concepts in order to enhance their meaningful and raise their higher order learning skills. Third, while the results of this and other studies on using digital concept maps are limit and not conclusive. Consequently, more research should be conducted to test further the effect of digital concept mapping as strategy to reap the benefits of using concept maps on students' achievement and attitude.

Using digital-based concept mapping as a new paradigm for teaching is an attempt to inject a new teaching approach. Educators are challenged to change their teaching methods and to enhance the students' learning environment. Therefore, using digital-based concept mapping holds great promise to improve what students learn and simultaneously develop the desired thinking skill competencies demanded by the teaching profession (Maas \& Leauby, 2005).

\section{References}

Akeju, O., Simpson, J., Rotimi, O. \& Kenni, M. (2011). Teaching with Concept Mapping Instructional Strategy in Nigeria Secondary Schools. International Association for Teaching and Learning (IATEL). Proceedings of the 2011 International Conference on Teaching, Learning and Change. 1 \& 2, 637643.

Alhomaidan A. (2015). The Effectiveness of Concept Mapping on Learning: A Study in a Saudi College-Level Context. American Journal of Educational Research, 3(8),10101014. doi: 10.12691/education-3-8-10.

Bellanca, J. (2007). A guide to graphic organizers: helping students organize and process content for deeper learning(2nd ed.). Thousand Oaks, CA: Corwin Press.

Birbili, M. (2006). apping Knowledge: Concept Maps in Early Childhood Education. Journal of Early Childhood Research \& Practice, $8(2)$.

BouJaoude, S., \& Attieh, M. (2008). The Effect of Using Concept Maps as Study Tools on Achievement in Chemistry. Eurasia Journal of Mathematics, Science \& Technology Education,4(3), 233-246.

Brinkerhoff, J. \& Gary B. (2013). The effect of concept mapping on student achievement in an introductory non-majors Biology class. European International Journal of Science and Technology, 2(8), 43-72.

Bruillard, E. \& Baron, L. (2000, August). Computer-based concept mapping: a review of 
a cognitive tool for students. Proceedings of Conference on Educational Uses of Information and Communication Technologies, Beijing, China.

Campbell, D. T., \& Stanley, J. C. (1963). Experimental and quasi-experimental designs for research on teaching. In N. L. Gage (Ed.), Handbook of research on teaching (pp. 171246). Chicago, IL: Rand McNally.

Chang, K., Sung, Y., \& Chen, I. (2002). The effects of concept mapping to enhance text comprehension and summarization. The Journal of Experimental Education, 71(1), 5-23. http://dx.doi.org/10.1080/00220970209602 054 .

Cheema, A. \& Mirza, M. (2013). Effect of concept mapping on students' academic achievement. Journal of Research and Reflections in Education, 7(2), 125-132.

Colosimo, A. \& Fitzgibbons, M. (2012). Teaching, Designing, and Organizing: Concept Mapping for Librarians. The Canadian Journal of Library and Information Practice and Research, 7(1), 1-15.

Çömek, A., Akınoğlu, O., Elmacı, E., \& Gündoğdu, T. (2016). The effect of concept mapping on students' academic achievement and attitude in science education. International Journal of Human Sciences, 13(1), 348-363. doi: 10.14687/ijhs.v13i1.3558.

Cooper, R. \& Schindler, S. (1998) 'Business Research Methods' Irwin, 6th Edition.

Dennis, D., Chinyama, K., \& Jumbe, J. (2014). The Effect of Using Concept Mapping on Student's Attitude and Achievement When Learning the Physics Topic of Circular and Rotational Motion. European Journal of Physics Education, 5(4), 10-29.

Emmanuel, O. (2013). Effects of concept mapping strategy on students' achievement in difficult chemistry concepts. Educational Research, 4(2), 182-189.

Erdogan, Y. (2009). Paper-based and computer-based concept mappings: The effects on computer achievement, computer anxiety and computer attitude. British Journal of Educational Technology, 40(5), 821-836. doi:10.1111/j.1467-8535.2008.00856.x.

Erdoğan, Y. (2016). An Investigation of the Effectiveness of Concept Mapping on Turkish Students' Academic Success. Journal of
Education and Training Studies, 4(6), 1-9. http://dx.doi.org/10.11114/jets.v4i6.1380.

Haladyna, M., Downing, M. \& Rodriguez, C. (2002). A review of multiple-choice itemwriting guidelines for classroom assessment. Applied Measurement in Education, 15(3), 309-334.

Hiemstra, R. (1994). Overcoming Resistance to Self-Direction in Adult Learning. San Francisco: Jossey-Bass, San Francisco.

Hwang, G.-J., Wu, C.-H., \& Kuo, F.-R. (2013). Effects of Touch Technology-based Concept Mapping on Students' Learning Attitudes and Perceptions. Educational Technology \& Society, 16 (3), 274-285.

Irvine, J., Cooper, K., \& Jones, G. (2006, November). Concept mapping to enhance student learning in a financial accounting subject, in Kent, J (ed), Proceedings of the Accounting Educators Forum, Sydney, CPA Australia and Charles Sturt University.

Luchembe, D., Chinyama, K., \& Jumbe, J.(2014). The Effect of Using Concept Mapping on Student's Attitude and Achievement When Learning the Physics Topic of Circular and Rotational Motion. European Journal of Physics Education, 5(4), 10-29.

Maas, J. \& Leauby, B. (2005). Concept mapping - exploring its value as a meaningful learning tool in Accounting Education. Global Perspectives on Accounting Education, (2), 7598.

Marzano, J.; Pickering, J.; \& Pollock, E. (2001). Classroom instruction that works. Research-based strategies for increasing student achievement. Alexandria, VA: Association for Supervision and Curriculum Development.

Novak J. \& Cañas, A. (2008). The Theory Underlying Concept Maps and How to Construct and Use Them, Technical Report IHMC CmapTools 2006-01. Retrieved March 2nd, 2016from: https://www.uibk.ac.at/tuxtrans/docs/T heoryUnderlyingConceptMaps-1.pdf.

Novak, D. (2006). The improvement of biology teaching. Indianapolis, New York: BobbsMerill Company.

Novak, J. D. (2010). Learning, creating, and using knowledge: Concept maps as facilitative tools in schools and corporations. Jour- 
nal of e-Learning and Knowledge Society, 6(3), 21-30.

eiska, P., Canas, J., Novak, D., \& Miller, L. (2008). Concept mapping for meaningful learning and assessment. The need for a paradigm shift in science education for post-soviet societies. (pp. 128-142). Frankfurt: Peter Lang Company.

Reushle S., Dorman, M., Evans, P., Kirkwood, J., McDonald, J. \& Worden, J. (2012). Critical Elements: Designing for Online Teaching. Retrieved April 16, 2016 from: http://www.ascilite.org/conferences/bris bane99/papers/reushledorman.pdf.

Ruiz-Primo, A., Schultz, E., \& Shavelson, J. (1997). Concept map-based assessment in science: Two exploratory studies. Center for Research on Evaluation, Standards, and Student Testing, Graduate School of Education \& Information Studies, University of California, Los Angeles. Retrieved February 16, 2016 from:

http://www.cse.ucla.edu/products/reports/ TECH436.pdf.

Sakiyo, J. \& Waziri, K. (2015). Concept mapping strategy: An effective tool for improving students' academic achievement in biology. Journal of Education in Science, Environment and Health (JESEH), 1(1), 56-62.

Sealfon, C. (2012). Student-Centered Teaching Methods: Council on Science and Technology. Retrieved March 15, 2016 from http://www.princeton.edu/ csealfon/res ources .

Soroush, S., \& Fatemeh, A.(2013). Do they know that they know? EFL learners' attitude towards concept mapping in listening comprehension. International Journal of Research Studies in Educational Technology, 2 (1), 57-70.

Williams, C. G. (1998). Using concept maps to assess conceptual knowledge of function. Journal for Research in Mathematics Education 25(4), 414-421. Retrieved March 19, 2016 from:

http://math.coe.uga.edu/olive/emat6990sp10 /JRME1998-Concept_Maps.pdf.

Yekta P. \& Nasrabadi, N. (2004). Concept mapping as an educational strategy to promote meaningful learning. Journal of Medical Education, 5(2), 155-165.
Yen, A. \& Yang, P. (2013). Integrating a digital concept mapping into a PPT slide writing Project. Turkish Online Journal of Educational Technology, 12 (3), 117-133.

Zinbarg, E., Yovel, I., Revelle, W., \& McDonald, P.(2006). Estimating generalizability to a latent variable common to all of a scale's indicators: A comparison of estimators for wh. Applied Psychological Measurement, 30 (2), 121-144. 


\section{Appendix 1 \\ Attitude Questionnaire}

\section{Dear student,}

The purpose of this survey is to collect data related to the students' attitudes towards the use of digital concepts mapping in teaching educational technology concepts. To conduct this study, we invite you to complete the survey. Data from the survey will be used for the purpose of this research only.

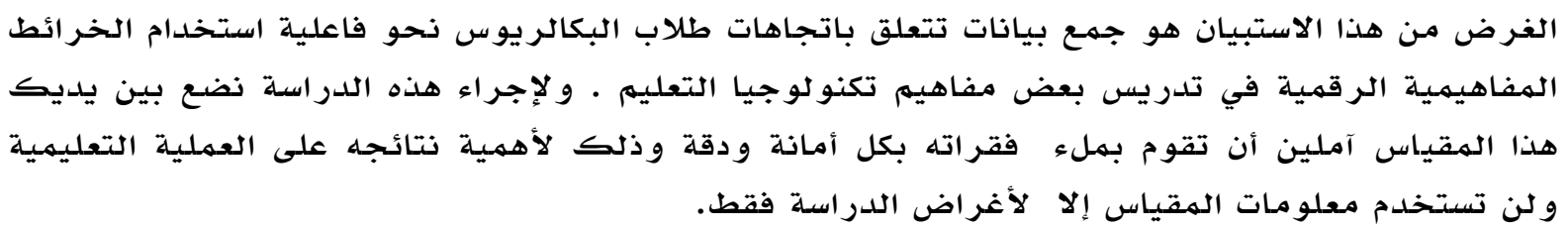

2. I think the concept map strategy is very creative. أعتقد أن إستراتيجية خر ائط الفاهيخ من الأساليب الخلاقة في التعلم.

3. I think the construction of the concept maps was very useful for my learning.

أعتقد أن إنثاء خر ائط المفاهيم مفيد جدا لتعلمي.

4. The constructions of concept maps activities were motivating me. كان بناء أنشطة خر ائط المفاهيم محفز جدا بالنسبة لي.

5. I feel that concept maps improved my thinking. أشعر بتحسين مستوى تفكيري بعد استخدام خر ائط الدفاهيم.

6. I think the concept maps promoted my ability to organize, think and relate to prior knowledge.

أعتق أن أسلوب خر ائط الدفاهيم عزز قدرني على التنظيم و التفكير وربط ذلك بالخبرات السابقة.

7. I will use concept maps when revising other topics related to my specialty.

سوف أقوم باستخدام أسلوب خر ائط المفاهيم عند مر اجعة موضو عات أخرى مرتبطة بتخصصي.

8. I will teach some topics using the concept maps strategy when I start my teaching at school.

سوف أقوم باستخدام أسلوب خر ائط المفاهيم في تدريس بعض الموضو عات عندما أبدأ في عملي في المدارس.

9. The construction of the concept map made me learn the concepts of educational technology better.

لاي رغبة في تعلم الكثير عن مفهوم خر ائط الدفاهيم وكيفية استخدامها.

10. I prefer the traditional method of analysing topics more than using a concept map.

أفضل استخدام الأساليب التقليدية للقيام بتحليل الموضو عات أكثر من استخدام أسلوب خر ائط المفاهيم.

11. Instead of simplifying, the concept map just confused me more.

بدلا من تبسيط المفاهيم عملت خر ائط المفاهيم على تعقيدها بالنسبة لي. 


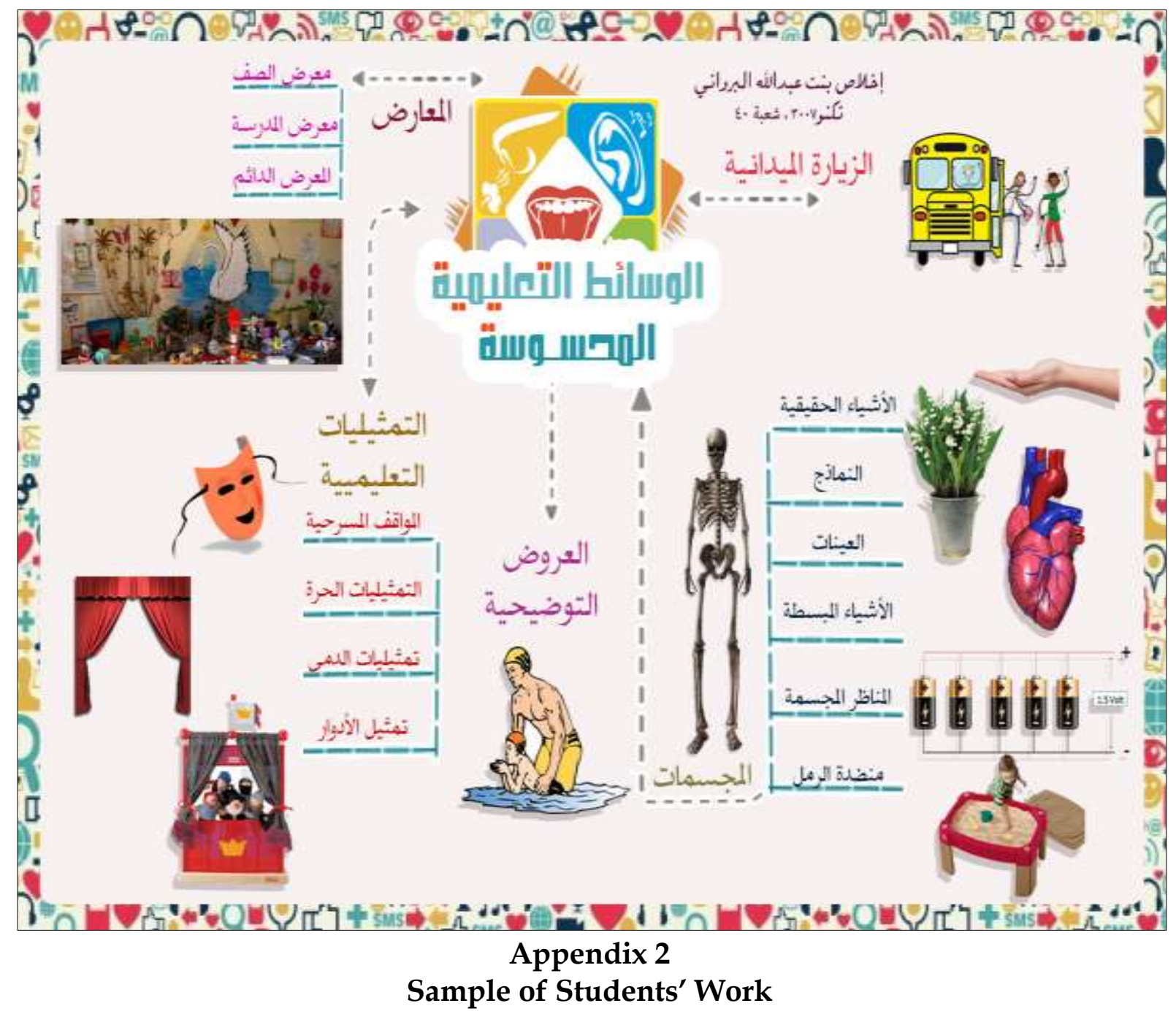

